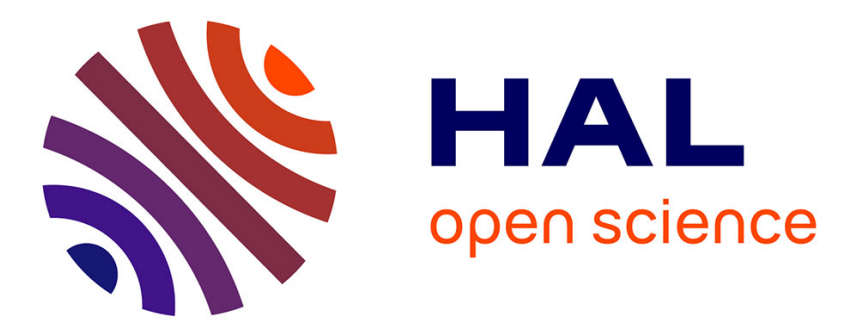

\title{
Evaluation of mTHPC-loaded PLGA nanoparticles for in vitro photodynamic therapy on C6 glioma cell line
}

G. Bœuf-Muraille, Guillaume Rigaux, Maité Callewaert, N. Zambrano, L. van Gulick, Valérie Gaëlle Roullin, C. Terryn, Marie-Christine Andry, Françoise Chuburu, S. Dukic, et al.

\section{To cite this version:}

G. Bœuf-Muraille, Guillaume Rigaux, Maité Callewaert, N. Zambrano, L. van Gulick, et al.. Evaluation of mTHPC-loaded PLGA nanoparticles for in vitro photodynamic therapy on C6 glioma cell line. Photodiagnosis and Photodynamic Therapy, 2019, 25, pp.448-455. 10.1016/j.pdpdt.2019.01.026 . hal-02434447

\section{HAL Id: hal-02434447 \\ https://hal.science/hal-02434447}

Submitted on 22 Oct 2021

HAL is a multi-disciplinary open access archive for the deposit and dissemination of scientific research documents, whether they are published or not. The documents may come from teaching and research institutions in France or abroad, or from public or private research centers.
L'archive ouverte pluridisciplinaire HAL, est destinée au dépôt et à la diffusion de documents scientifiques de niveau recherche, publiés ou non, émanant des établissements d'enseignement et de recherche français ou étrangers, des laboratoires publics ou privés.

\section{(ㄷ)(1) $\$$}

Distributed under a Creative Commons Attribution - NonCommerciall 4.0 International 


\title{
Evaluation of mTHPC-loaded PLGA nanoparticles for in vitro photodynamic therapy on C6 glioma cell line
}

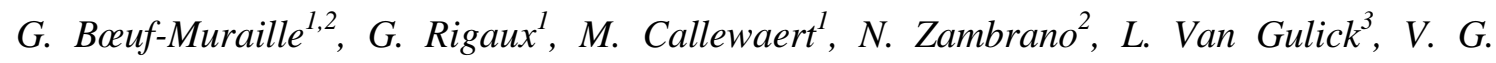

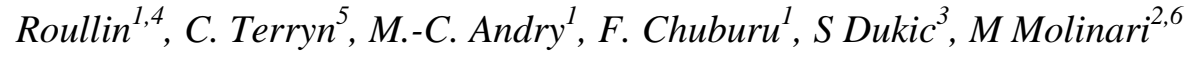

${ }^{1}$ Institut de Chimie Moléculaire de Reims, CNRS UMR 7312, University of Reims Champagne Ardenne, 51687 Reims Cedex 2, France.

${ }^{2}$ Laboratoire de Recherche en Nanosciences LRN EA 4682, University of Reims Champagne-Ardenne URCA, 51685 Reims Cedex 2, France.

${ }^{3}$ BioSpecT, Faculty of Pharmacy, University of Reims Champagne Ardenne URCA, 51100 Reims, France

${ }^{4}$ Laboratoire de Nanotechnologies Pharmaceutiques, Faculté de Pharmacie, Université de Montréal, Montréal H3T 1J4, Canada

${ }^{5}$ PICT platform, University of Reims Champagne-Ardenne, 51100, Reims, France

${ }^{6}$ CBMN CNRS UMR 5248, Université de Bordeaux, INP Bordeaux, 33600 Pessac, France

\begin{abstract}
Photodynamic therapy (PDT) is a very attractive strategy to complement or replace common cancer treatments such as radiotherapy, surgery, and chemotherapy. If some molecules have shown their efficiency as photosensitizers (PS), many issues have to be solved such as the inherent cytotoxicity of the PS or its hydrophobic properties causing limitation in their solubility and leading to side effects. In this study, the encapsulation of an approved PS, the meso-tetra hydroxyphenylchlorine (mTHPC, Foscan®) within biocompatible and biodegradable poly(D, L-lactide-co-glycolide) acid (PLGA) NPs prepared by the nanoprecipitation method was studied. The mTHPC-loaded NPs $($ mTHPC $\subset$ PLGA NPs)
\end{abstract}


were analyzed by UV-Visible spectroscopy to determine the efficiency of mTHPC encapsulation, and by dynamic light scattering (DLS) and atomic force microscopy (AFM) to determine mTHPC $\subset$ PLGA NPs sizes, morphologies and surface charges. The longitudinal follow-up of mTHPC release from the NPs indicated that $50 \%$ of the encapsulated PS was retained within the NP matrix after a period of five days. Finally, the cytotoxicity and the phototoxicity of the mTHPC $\subset$ PLGA NPs were determined in murine C6 glioma cell lines and compared to the ones of mTHPC alone. The studies showed a strong decrease of mTHPC cytotoxicity and an increase of mTHPC photo-cytotoxicity when mTHPC was encapsulated. In order to have a better insight of the underlying cellular mechanisms that governed cell death after mTHPC $\subset$ PLGA NPs incubation and irradiation, annexin V staining tests were performed. The results indicated that apoptosis was the main cell death mechanism. 


\section{INTRODUCTION}

PhotoDynamic Therapy (PDT) is a clinically approved and minimally invasive therapeutic procedure that can exert a selective cytotoxic activity toward malignant cells. Clinical studies revealed that PDT can be performed as an alternative or as an adjuvant to other therapies such as radiotherapy, surgery and chemotherapy ${ }^{1}$, for the treatment of superficial tumors. The procedure involves the application of a molecule called photosensitizer (PS), followed by the irradiation of the area to be treated at the wavelength corresponding to an absorbance band of the PS. The combination of the PS and light will produce reactive oxygen species and singlet dioxygen $\left({ }^{1} \mathrm{O}_{2}\right)$, leading to cell death.

The highest limitation of PDT effect lies in the drug itself. Indeed, an ideal PS has to possess adapted chemical and photophysical properties. The compound has (1) to be stable and chemically pure, (2) to be soluble in biological environments, (3) to be safe in the dark (so called dark toxicity), (4) to have a high molar extinction coefficient for an absorbance PS band with a strong tissue penetration and (5) to accumulate with high concentration in targeted tissues ${ }^{2,3}$. Currently no molecule possesses all these properties.

Porphyrins (including chlorins) are the most frequently used PS with high efficiency in vivo. Among these molecules, mTHPC (Foscan $®)$, which is a chlorin, is approved for the palliative treatment of advanced head and neck cancer by the European Medicines Agency since October 2001. This PS is a highly hydrophobic molecule that can be excited at $652 \mathrm{~nm}$ (at this wavelength, the light penetration is about $7 \mathrm{~mm})^{4}$. However, $\mathrm{mTHPC}$ is prone to aggregation, its aggregated form is less photoactive and binds strongly to serum proteins ${ }^{5}$. Rapid uptake of aggregates by cells of the reticuloendothelial system may lead to higher inter-patient variability of mTHPC accumulation in tissues ${ }^{6}$. 
In order to further improve the treatments, one promising solution is the encapsulation of photosensitizers. This could help to improve PS solubility and to help tissue targeting while preserving or improving PS therapeutic effect.

In this context, our goal was to develop biocompatible nanoparticles able to encapsulate mTHPC in the form of the Foscan ${ }^{\circledR}$ formulation. In this respect, polymeric nanoparticles (NPs) are ideal candidates for the vectorization of drugs. Among them, poly(D, L-lactide-coglycolide) (PLGA) is FDA-approved for human use ${ }^{7,8}$. PLGA and its various derivatives have set the basis to develop micro- or nanoparticles encapsulating therapeutic drugs for controlled release applications ${ }^{9}$. Indeed, they present inherent advantages over the conventional devices, such as extended release rates in addition to their biocompatibility/biodegradability and ease of administration via injection. Moreover, their chemical nature seems to perfectly match that of the hydrophobic drugs ${ }^{8,10}$. Furthermore, due to the enhanced permeability and retention effect (EPR effect) ${ }^{11}$, NPs can be uptaken by tumor tissues, which can be useful to increase drug dose within these tissues, even if the reproducibility of this mechanism seems to be controversial $^{12}$. To circumvent this drawback, methods such as ligand grafting at the NP surface, combination of light or radiation therapy to NP administration can for instance be used to enhance drug penetration to the inner layers of the tumor ${ }^{12}$.

In this paper, the encapsulation of mTHPC into PLGA nanoparticles (mTHPC $\subset$ PLGA NPs) is described and its encapsulation efficiency evaluated by UV-visible spectroscopy. The size, $\zeta$-potential and NP morphology were analysed by dynamic light scattering (DLS), electrophoretic light scattering (ELS) and atomic force microscopy (AFM) respectively. The release profile of mTHPC from NPs was followed by UV-Visible spectroscopy. Dark cytotoxicity and photocytotoxicity of mTHPC $\subset$ PLGA NPs were evaluated towards a murine C6 glioma cell line by confocal and fluorescence microscopy, and compared to the ones of non-encapsulated mTHPC. The C6 cell line, histologically classified as an astrocytoma was 
chosen because it fulfils commonly accepted criteria for an ideal in vivo experimental brain tumor model ${ }^{13}$. Furthermore it exhibited the greatest number of genes whose expression was similar to that reported for human brain tumors. Annexin $\mathrm{V}$ tests were finally performed in order to have a better insight of the cell death mechanisms, induced by irradiation of C6 glioma cells treated with mTHPC $\subset$ PLGA NPs.

\section{MATERIALS AND METHODS}

\section{General}

mTHPC (Foscan $\left.{ }^{\circledR}\right)$ was a generous gift of Biolitec Pharma Ltd. (Jena, Germany). Poly(lactide-co-glycolide) (PLGA $50: 50, \mathrm{RH} 503 \mathrm{H})$ was purchased from Boeringher Ingelheim (Germany) and Poloxamer 188 (P188, i.e.Pluronic ${ }^{\circledR}$ F-68 polyethyleneglycol-copolypropyleneglycol-co-polyethyleneglycol) from Sigma Aldrich (France). Sterile water for injections (Laboratoire Aguettant, Lyon, France) was systematically used for nanoparticle preparation and analysis.

UV-visible absorption spectra of mTHPC solutions $\left(\sim 10^{-6} \mathrm{M}\right)$ were recorded with Varian Cary 60 spectrometer using solvents of spectrophotometric grade (DMSO and glycofurol i.e. tetrahydrofurfuryl alcohol polyethylene glycol ether, Sigma Aldrich (France)). Absorption spectrum of mTHPC in DMSO exhibited the characteristic Soret and Qbands at 418, 516, 543, 597 and $652 \mathrm{~nm}$ respectively ${ }^{14}$. mTHPC molar extinction coefficient determined in DMSO at $652 \mathrm{~nm}$ was of $39800 \mathrm{~L} \mathrm{~mol}^{-1} \mathrm{~cm}^{-1}$.

\section{Nanoparticle preparation}

PLGA NPs were synthesized using a modified nanoprecipitation method ${ }^{15}$. Briefly, $50 \mathrm{mg}$ of PLGA $(1 \% \mathrm{w} / \mathrm{v})$ and $50 \mathrm{mg}$ Pluronic ${ }^{\circledR}$ F68 (1\% w/v) were dissolved in glycofurol $(5 \mathrm{~mL})$ in presence (or not for unloaded NPs) of mTHPC. This solution was then poured at a constant 
flow rate $\left(0.2 \mathrm{~mL} \cdot \mathrm{min}^{-1}\right)$ under moderate magnetic stirring into $75 \mathrm{~mL}$ of an aqueous phase containing $0.01 \% \mathrm{w} / \mathrm{v}$ Pluronic $\circledR$ F68. NPs were spontaneously formed upon glycofurol diffusion into the aqueous phase. Potential aggregates were removed by centrifugation $(2415 \mathrm{~g}$ for $5 \mathrm{~min}$, at room temperature). The raw nanosuspension $(10 \mathrm{~mL})$ was purified by dialysis (three cycles of $10 \mathrm{~h}$ ) against sterile water $(1 \mathrm{~L})$ at room temperature, using a cellulose membrane with a MWCO of $25 \mathrm{kDa}$ (Spectrum, Spectrapor ${ }^{\circledR} 6.0$ ).

\section{Determination of encapsulation efficiencies}

mTHPC loading was determined spectrophotometrically on raw and dialysed nanosuspensions. $10 \mathrm{~mL}$ of $\mathrm{mTHPC} \subset$ PLGA nanosuspension were centrifuged for $1 \mathrm{~h}$ at $4^{\circ} \mathrm{C}$, at $23200 \mathrm{~g}$ to discard the supernatant. The NP pellet was freeze-dried to remove traces of water and then re-solubilized in $2 \mathrm{~mL}$ DMSO prior to UV-vis spectrophotometry analysis. The mTHPC content was determined at $652 \mathrm{~nm}$ thank to the value of the molar extinction coefficient previously determined (39 $\left.800 \mathrm{~L} \mathrm{~mol}^{-1} \mathrm{~cm}^{-1}\right)$. mTHPC entrapment efficiency (EE, $\%$ ) and drug loading (DLE, \% w/w) were calculated by Eqs. (1) and (2), respectively:

Equation (1)

$$
\mathrm{EE}(\%)=\frac{m T H P C \text { mass in nanoparticles }}{m T H P C \text { mass introduced in the synthesis }} \times 100
$$

Equation (2)

$$
\operatorname{DLE}(\%)=\frac{m T H P C \text { mass in nanoparticles }}{\text { total mass of recovered nanoparticles }} \times 100
$$

\section{Particle size analysis and $\zeta$-potential measurements}

Unloaded and mTHPC $\subset$ PLGA NPs sizes were determined by Dynamic Light Scattering (DLS) with a Zetasizer Nano ZS (Malvern Zetasizer Nano-ZS, Malvern Instruments, Worcestershire, UK). Mean hydrodynamic diameters (Z-ave) and polydispersity indexes are calculated with the cumulants method from the intensity data by the Zetasizer software (v7.12, Malvern). Each nanosuspension was analyzed in triplicate at $20^{\circ} \mathrm{C}$ and a scattering angle of $173^{\circ}$, after $1 / 20$ dilution in water. Pure water was used as a reference dispersing medium. 
Zeta potential ( $\zeta$-potential or ZP) data were collected through Electrophoretic Light Scattering $\left(20^{\circ} \mathrm{C}, 150 \mathrm{~V}\right)$, in triplicate for each sample (Malvern Zetasizer Nano-ZS, Malvern Instruments, UK), using water as the dispersant medium. The instrument performance was checked with Malvern $-68 \mathrm{mV}$ standard before each analysis cycle.

\section{Morphological studies}

The AFM images were acquired in a liquid cell with a Bioscope Catalyst (Brüker Nano) in tapping mode. The parameters were set to avoid strong interactions between the tip and the soft sample, and then a possible deformation of the NPs. A silicon nitride tip with a spring

constant of $0.24 \mathrm{~N} \mathrm{~m}^{-1}$ was used for topographical images. AFM images were generated with a scan rate of $0.5 \mathrm{~Hz}$ and 512 lines per image. Experiments were performed at constant room temperature. During the scans, feedback gains were increased to the value just below the feedback started to oscillate. Images were processed only by flattening to remove background slopes.

\section{mTHPC release profile}

The ability of these delivery systems to release their payload was explored in vitro using phosphate buffer pH 7.4 at $37^{\circ} \mathrm{C}$. Briefly, dialysis bags (Spectrum, Spectra Por®6.0, MWCO $25 \mathrm{kDa}$ ) containing $10 \mathrm{~mL}$ of mTHPC $\subset$ PLGA nanosuspensions were immersed in $1 \mathrm{~L}$ phosphate buffer $\mathrm{pH} 7.4$ at $37.0 \pm 0.2{ }^{\circ} \mathrm{C}$ and mechanically stirred at $50 \mathrm{rpm}$ in a USP Dissolutest system. At various pre-determined endpoint, one dialysis bag was withdrawn and its NP content harvested by centrifugation. mTHPC loading was determined after pellet resolubilisation in DMSO by UV-vis spectrophotometry at $652 \mathrm{~nm}$, as described previously.

\section{Cytotoxicity studies}

In order to investigate the cytotoxicity of free mTHPC and mTHPC $\subset$ PLGA NPs on tumour cells, C6 glioma cells were treated with various concentrations over $24 \mathrm{~h}$ and MTT tests were conducted. Cells $\left(1.5 \times 10^{4}\right.$ cells. $\left.\mathrm{mL}^{-1}\right)$ were seeded in 96-well plates and grown in 
Dulbecco's modified Eagle Medium Nutriment Mixture F-12, enriched with $10 \%$ FCS and $1 \%$ antibiotics (penicillin $50 \mathrm{U} / \mathrm{ml}$, streptomycin $50 \mathrm{mg} / \mathrm{ml}$ ). Thereafter, cells were incubated with various concentrations of mTHPC and mTHPC $\subset$ PLGA NPs. Double control was achieved, with untreated cells on the one hand, and with cells treated with equivalent dilutions of unloaded NPs on the other hand. Cells were incubated for $24 \mathrm{~h}$ at $37^{\circ} \mathrm{C}, 5 \% \mathrm{CO}_{2}$. After carefully removing the medium and rinsing the cells with D-PBS, cell survival was determined by a MTT assay ${ }^{16}$. Cells were mixed with $17 \mu \mathrm{L}$ of MTT solution $(2.5 \mathrm{mg} / \mathrm{mL})$ and incubated $3 \mathrm{~h}$ at $37^{\circ} \mathrm{C}$ and $5 \%$ of $\mathrm{CO}_{2}$. The supernatant was discarded and the formazan crystals salt were solubilized by adding $100 \mu \mathrm{L}$ of DMSO (Sigma Aldrich). The absorbance was measured in an automated microplate reader at $560 \mathrm{~nm}$ (Perkin Elmer 1420 Multilabel counter). Cytotoxicity was expressed as percentage of controls (untreated cells) by visible spectrophotometry Victor3V at $560 \mathrm{~nm}$ (Perkin Elmer 1420 Multilabel counter). The Prism ${ }^{\mathrm{TM}}$ program was used to determine $\mathrm{IC}_{50}$ for the various treatments (GraphPad Software, San Diego, USA).

\section{Photocytotoxicity evaluation}

The response of free mTHPC and mTHPC $\subset$ PLGA NPs to light was also tested in vitro in C6 glioma cells. After the treatment of the cells, they were placed in a videomicroscope Axiovert 200 (Zeiss) and irradiated with a mercury lamp through a filter of excitation band of $(640 \pm 30) \mathrm{nm}$. The temperature was fixed at $37^{\circ} \mathrm{C}$ and the percentage of $\mathrm{CO}_{2}$ at $5 \%$. The viability of treated cells was determined just after irradiation by two methods: observation of the fluorescence of propidium iodide and tests with trypan blue.

Propidium iodide: Cells $\left(1.5 \times 10^{4}\right.$ cells. $\left.\mathrm{mL}^{-1}\right)$ were seeded in Iwaki glass boxes background (Asahi Techno Glass Corporation) at the concentration of $7.3 \times 10^{-7} \mathrm{M}\left(0.5 \mu \mathrm{g} . \mathrm{mL}^{-1}\right)$ of mTHPC (free or encapsulated). Just before irradiation, $1 \mu \mathrm{L}$ of propidium iodide is added for $1 \mathrm{~mL}$ of enriched medium. Optical and fluorescence images $(512 \times 512$, Metamorph 


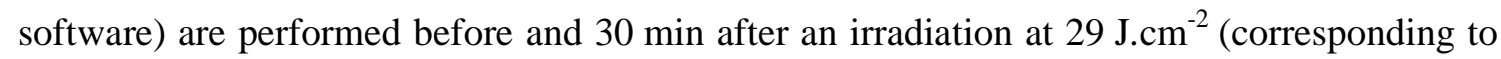
1 hour of irradiation of a surface of $1.55 \mathrm{~cm}^{-2}$ with a power of $12.5 \mathrm{~mW}$ ) or $58{\mathrm{~J} . \mathrm{cm}^{-2}}^{-2}$ (corresponding to 2 hours of irradiation in the same conditions). Such energy values were chosen to highlight the qualitative action of PS on cells accordingly to other studies ${ }^{17,18}$.

Trypan blue: Cells $\left(1.5 \times 10^{4}\right.$ cells. $\left.\mathrm{mL}^{-1}\right)$ were seeded in 24 -well plates at the concentration of $7.3 \times 10^{-7} \mathrm{M}\left(0.5 \mu \mathrm{g} \cdot \mathrm{mL}^{-1}\right)$ of mTHPC (free or encapsulated). The same irradiation conditions were used $\left(29 \mathrm{~J} . \mathrm{cm}^{-2}\right.$ and $\left.58 \mathrm{~J} . \mathrm{cm}^{-2}\right)$ to determine the quantitative influence of the light dose. Just after irradiation, the wells were rinsed and cells were detached with $200 \mu \mathrm{L}$ of trypsin $0.05 \%$ /EDTA and resuspended in D-PBS. After that, $100 \mu \mathrm{L}$ of blue trypan solution $(0.4 \%$, Sigma Aldrich) and $100 \mu \mathrm{L}$ of D-PBS with cells were added. Colored cells were counted under the optical microscope.

\section{Determination of the cellular death mechanism}

To investigate the cell death mechanism (necrosis or apoptosis), tests based on the detection of Annexin V were performed using Annexin V \& Dead Cell Kit and the cell analyzer Muse ${ }^{\circledR}$. Using similar protocols as previously described for cytotoxicity evaluation, cells were seeded at the concentration of $0.5 \mu \mathrm{g} \cdot \mathrm{mL}^{-1}$ of $\mathrm{mTHPC}$ (free or encapsulated). After irradiation at a smaller light dose of $10 \mathrm{~J} . \mathrm{cm}^{-2}$, cells were incubated during $40 \mathrm{~h}$. For these tests, a smaller irradiation dose was chosen compared to the previous experiments. Indeed, to perform this test and get relevant results, it is better to look at the cells a long time after irradiation as the apoptosis is a longer process. The test was then performed 40 hours after irradiation. Regarding the irradiation dose, it was decided to lower it to avoid the death of all the cells. Then dead cells floating in the medium were removed and collected. The adherent cells were rinsed with PBS before adding $500 \mu \mathrm{L}$ of trypsin to detach them. The medium containing dead cells collected previously was mixed with this cell suspension. All these cells were centrifuged for $5 \mathrm{~min}$ at $4^{\circ} \mathrm{C}$ at $1500 \mathrm{rpm}$. The supernatant was removed and cells 
resuspended in a PBS solution with $1 \%$ SVF before counting using KOVA® Glasstic ${ }^{\circledR}$ slide (KOVA). To guarantee a rational labelling, cell suspension was diluted at a density range between $2 \times 10^{5}$ and $2 \times 10^{6}$ cells $/ \mathrm{mL}$. A $100 \mu \mathrm{L}$ cells solution volume was mixed with an equal volume of Annexin V solution and kept during 20 min in the dark ambient temperature. Cells were analyzed with the Muse Cell Analyzer ${ }^{\circledR}$ (Millipore, France). The viability slider was adjust and the settings were refine for the Annexin V vs viability plot to identify all populations, live, dead, and apoptotic cells. Positive and negative control were used to confirm population cell status. Results were computed with Muse Analysis ${ }^{\circledR}$ software (Millipore, France) to determine the apoptosis proportion.

\section{Results and Discussion}

Nanoparticle synthesis and characterization: mTHPC $\subset$ PLGA NPs nanoparticles were synthesized from FDA-approved, pharmaceutical-grade PLGA through the simple and easilyscalable nanoprecipitation process $^{15}$, using exclusively non-toxic ingredients ${ }^{13,19}$. Nanoparticle suspensions displayed monodisperse size distributions $(\mathrm{PdI}<0.15)$ with an intensity-averaged diameter determined by DLS around $120 \mathrm{~nm}(\mathrm{Z}$-ave $=122 \pm 15 \mathrm{~nm})$ which is in agreement with the observed sizes for PLGA NPs ${ }^{20}$. The incorporation of mTHPC within PLGA matrix increased the NP mean diameter ${ }^{6}$ (unloaded NP mean diameter $92 \pm 12 \mathrm{~nm}$ ) but within acceptable size for $i v$ administration.

AFM observations in liquid confirmed these values and showed NPs of a well-defined spherical shape and a very narrow distribution (Figure 1). 


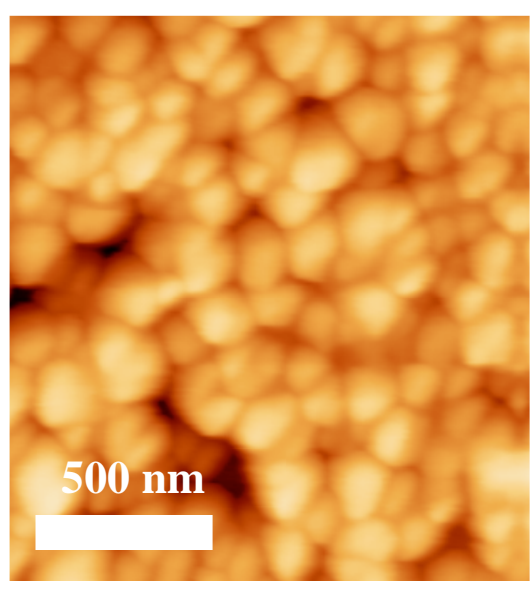

Figure 1: AFM images of $m T H P C \subset P L G A N P S$

ELS measurements showed that dialysed mTHPC-loaded NPs exhibited a negative surface charge of $-34.2 \pm 7.2 \mathrm{mV}$ which also corresponds to the value of the free NPs prepared in the same conditions. This shows that the mTHPC does not seem to be on the surface of the NPs but inside. Nevertheless, this $\zeta$-potential is superior to what is expected for PLGA-based NPs prepared in the same conditions in the absence of Pluronic ${ }^{\circledR} \mathrm{F} 68\left(\sim-50 \mathrm{mV}^{21}\right)$. This characteristic demonstrates that a partial PEG coating occurred due to the co-precipitation of PLGA and Pluronic ${ }^{\circledR}$ F68 ${ }^{22}$. Therefore, orientation of PEG segments to the NP-water interface allowed partially masking carboxylic end-groups at the PLGA NP surface. This participated to the formation of a hydrophilic PEG corona ${ }^{23}$ contributing to render those NPs less vulnerable to opsonization ${ }^{24}$.

mTHPC encapsulation efficiency was then determined by spectrophotometric titration. mTHPC photosensitizer was incorporated within PLGA NPs with an encapsulation efficiency of $53 \%$ obtained after dialysis. This value is significantly higher than the one obtained for the encapsulation of mTHPC in PLGA NPs by an emulsion-diffusion-evaporation technique $(25 \%)^{25}$. It should nevertheless be noticed that this loading efficiency is superior in micelles ${ }^{26}$ $(80 \%)$ or in solid lipid nanoparticles ${ }^{6}(81-95 \%)$.

The in vitro mTHPC release profile from the synthesized PLGA nanoparticles was then 
performed in phosphate buffer $\left(\mathrm{pH} 7.4,37^{\circ} \mathrm{C}\right.$, Figure 2$)$. The release profile was biphasic and the values in agreement with those obtained for similar $\mathrm{NPs}^{10,27}$. An initial burst effect occurred since at least $45 \%$ of mTHPC was released within the first $24 \mathrm{~h}$. This probably corresponded to mTHPC diffusion located near the NP surface. Then a second release step occurred for which a slower mTHPC release was observed between the fifth and the fourteenth day. This second phase probably corresponded to the mTHPC diffusion from the core of nanoparticles to the aqueous medium.

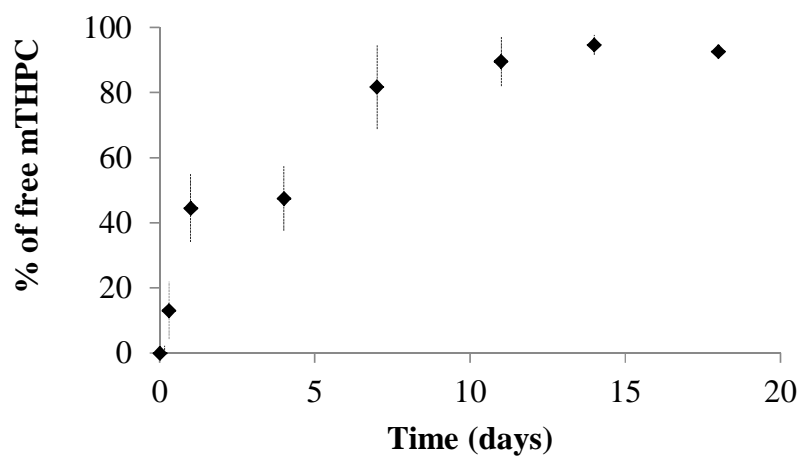

Figure 2. Release profile of free $m T H P C$ as a function of time, in a phosphate buffer $p H 7.4$ at $37^{\circ} \mathrm{C}(n=3$, triplicate experiments $)$.

This result showed that after five days, $50 \%$ of the initial amount of mTHPC content remained within the NPs.

\section{Biological study with mTHPC-loaded PLGA NPs}

The physico-chemical studies clearly showed that the nanoparticles are stable in time, contains the PS and can be synthesized with a good reproducibility under sterile conditions. Therefore, tests on living cells were performed: MTT tests were conducted to evaluate the dark cytotoxicity, as well as the cytotoxicity after PS activation by light. To highlight the contribution of nanoparticle formulation of PS, experiments were conducted under the same conditions on cells treated with free mTHPC and mTHPC $\subset$ PLGA respectively. Unloaded nanosuspensions were used as controls to check the non-toxicity of the PLGA NPs. 
Cytotoxic activity: Unloaded NPs were nontoxic to the C6 cell lines, as shown on figure 4. It confirmed previous data reported in the literature ${ }^{10,28}$. The effect of free mTHPC on cell viability was compared to those of encapsulated mTHPC in PLGA NPs. The cell survival profiles showed a concentration dependent cytotoxicity of the free PS. The inhibition concentration $\mathrm{IC}_{50}$ of free mTHPC was determined at $5.8910^{-6} \mathrm{M} \pm 0.5910^{-6} \mathrm{M}$, which is coherent with the value of literature ${ }^{18,27,29}$. For the mTHPC-loaded NPs and in the concentration range tested in this study, the low toxicity prevents the calculation of an IC50, as the cell survival percentage never drops below $80 \%$ (Fig. 3). A slight toxicity was noticed from a concentration around $10^{-5} \mathrm{M}$. These results clearly demonstrated that the encapsulation of mTHPC reduced its cytotoxicity: at $2.010^{-5} \mathrm{M}$, free mTHPC led to the death of almost all the cells while only $20 \%$ of the cells died in the presence of mTHPC $\subset$ PLGA NPs . The poor cytotoxicity of mTHPC-loaded NPs has been already observed towards other cell lines (A549, MCF10A neoT and U937) ${ }^{27}$ and with lipid $\mathrm{NPs}^{6}$ as well.

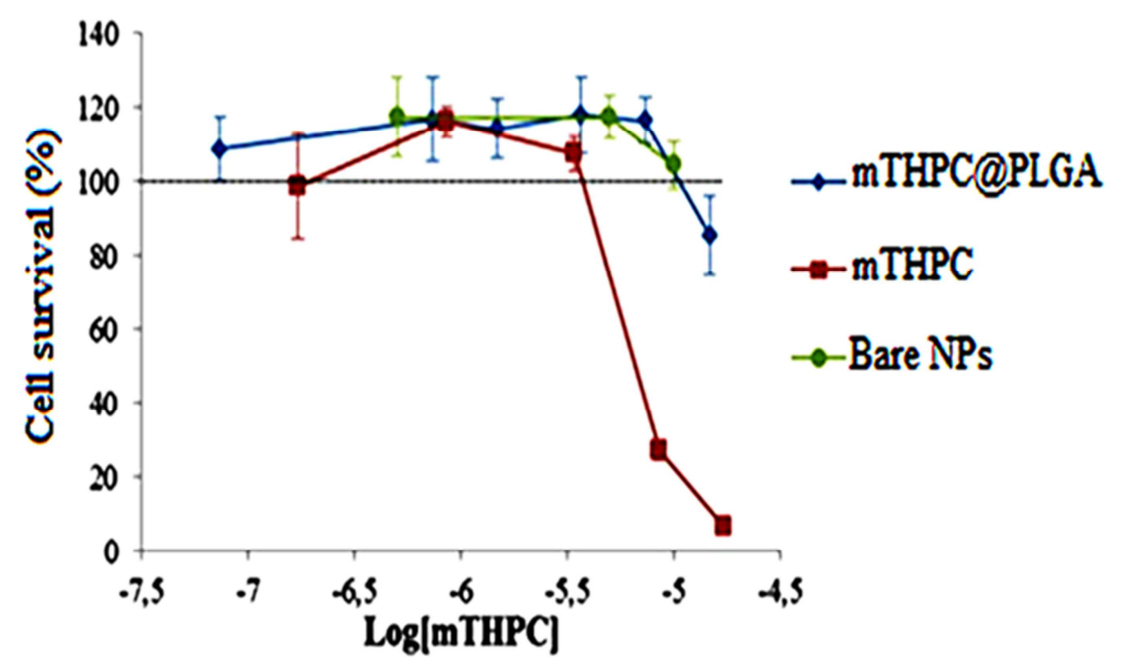

Figure 3. Cytotoxicity of free mTHPC, mTHPC-loaded NPs and bare NPs (for bare NPs, values of toxicity are obtained with the same quantity of NPs in contact with cells $-n=3$, triplicate experiments).

Regarding those results, a concentration of mTHPC of $7.310^{-7} \mathrm{M}(0.5 \mu \mathrm{g} / \mathrm{mL})$ was chosen to evaluate the phototoxicity of both free and encapsulated PS. This concentration is 10 times 
superior to the $\mathrm{IC}_{50}$ for free $\mathrm{mTHPC}$ preventing any direct toxicity of the PS, even if a release from loaded NPs occurred.

Photocytotoxic activity: The photoxicity measurements were performed with free mTHPC and compared to the loaded PLGA NPs. For each experiments, images of cells treated with free mTHPC or with loaded NPs were captured before and after irradiation. The panel A of figure 4 showed the optical (left) and the fluorescence (right) images of non-treated cells (no free mTHPC or loaded NPs) before and after irradiation. No change before and after irradiation has been observed in the optical images and the fluorescence of the propidium iodide was not observed before and after irradiation, proving that the irradiation dose by itself did not affect the cell integrity. The same set of experiments was firstly performed on the cells treated with free mTHPC. Panel B of figure 4 compared the optical and the fluorescence images of the cells treated with free mTHPC, before and after irradiation. Before irradiation, a weak signal of fluorescence was detected in the cell cytoplasm due to the emission of mTHPC itself. The mTHPC was detectable in all cells but did not seem to enter the nucleus (fig. 4, panel B and supplementary material ESI1). This is coherent with different studies performed with mTHPC which shows its localization within the lysosomes, the mitochondria or in the plasmic membranes ${ }^{30-34}$. After $30 \mathrm{~min}$ of light irradiation, optical images showed morphological changes and a very strong fluorescence signal due to the propidium iodide (and not to the mTHPC fluorescence) was detected within the nucleus, which is directly linked to the cell death. The presence of this strong fluorescence signal inside of the nucleus is a proof that the nuclear membrane has been damaged after the irradiation, enabling the propidium iodide to enter in the cell nucleus ${ }^{35}$. When inside the nucleus, it links to DNA leading to the appearance of this strong fluorescence signal characteristic of necrotic cells. The appearance of the strong fluorescence after irradiation, while no such signal was detected for the non-treated cells, clearly showed that the mTHPC was responsible of the cell death 
after irradiation of the C6 cells thanks to a PDT effect. The same experiments have been performed with cells treated with mTHPC-loaded NPs (fig. 4, panel C). As for free mTHPC, the loaded NPs were localized within all the cells and in the cytoplasm as observed thanks to mTHPC fluorescence (see also supplementary material ESI2). The PDT effect was still observable after the irradiation of the mTHPC-loaded PLGA NPs. Without irradiation, only a weak fluorescence signal coming for the mTHPC could be observed while after irradiation, the fluorescence intensity was more important and localized in the cell nucleus coming from the propidium iodide emission and indicating the cell death. Then, the mTHPC encapsulation was not detrimental to its PDT effect and did not seem to affect the cellular uptake. The internalization of PLGA nanoparticles within the nucleus is coherent with other studies that have shown that they can be internalized by pinocytosis as well as by dependent clathrin endocytosis mechanisms ${ }^{10,36,37}$.

To confirm the PDT effect for free mTHPC and mTHPC loaded NPs, blue trypan tests were performed with the same samples and in the same irradiation conditions. The blue trypan tests allow to get quantitative results about the cellular death. The blue trypan is a dye that easily go through deteriorated plasma membrane of dead cells leading to the blue coloration of the cytoplasm while it remains outside the living cells ${ }^{38}$. The treatment with $7.3 \times 10^{-7} \mathrm{M}$ of mTHPC induced $62 \% \pm 6 \%$ of cell death by for free mTHPC and $68 \% \pm 0.5 \%$ for mTHPCloaded NPs at $29{\mathrm{~J} . \mathrm{cm}^{-2}}^{-}$(Table I). Under the same irradiation, no phototoxicity was measured for control cells, showing the efficiency of the PDT effect for both conditions. 

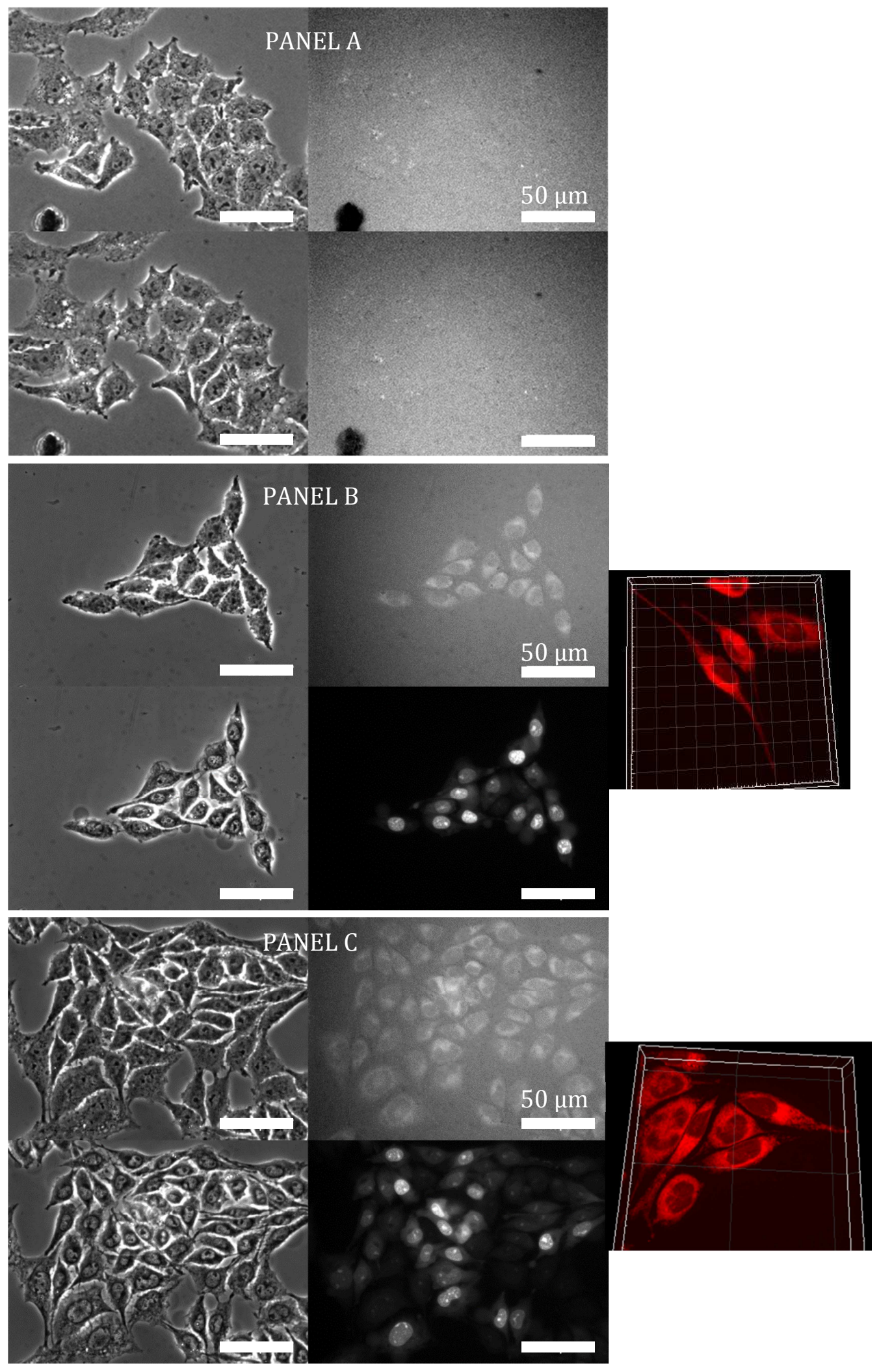

Figure 4: Panel A - Optical (left) and fluorescence images (right) of non-treated cells before

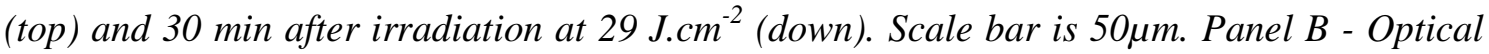


(left) and fluorescence images (middle) of mTHPC treated cells before (top) and 30 min after irradiation at $29 \mathrm{J.cm}^{-2}$ (down). Scale bar is $50 \mu \mathrm{m}$. On the right, $3 D$ reconstruction of the confocal fluorescence images before irradiation (see supplementary material ES1). Panel C Optical (left) and fluorescence images (middle) of mTHPC@PLGA treated cells before (top) and $30 \mathrm{~min}$ after irradiation at $29 \mathrm{J.cm}^{-2}$ (down). Scale bar is $50 \mu \mathrm{m}$. On the right, 3D reconstruction of the confocal fluorescence images before irradiation (see supplementary material ESI2).

To evaluate the effect of the irradiation dose on the PDT efficiency, the irradiation dose was tuned to $58{\mathrm{~J} . \mathrm{cm}^{-2}}^{2}$ (2 hours of irradiation instead of 1). The experiments were performed exactly in the same conditions than previously. The increase of the irradiation dose induced an enhancement of cellular death either for free mTHPC $(77 \% \pm 2 \%)$ or for encapsulated mTHPC $(88 \% \pm 1 \%)$. These results are particularly interesting as they were obtained just after the irradiation.

\begin{tabular}{|c|c|c|c|}
\hline Cellular death $(\%)$ & Control cells & $\begin{array}{l}\text { Cells treated } \\
\text { with free } \\
\text { mTHPC }\end{array}$ & $\begin{array}{l}\text { Cells treated with } \\
\text { mTHPC-PLGA NPs }\end{array}$ \\
\hline Irradiation $29 \mathrm{J.cm}^{-2}$ & $0.6 \% \pm 0.4 \%$ & $62 \% \pm 6 \%$ & $68 \% \pm 0.5 \%$ \\
\hline Irradiation $58{\mathrm{~J} . \mathrm{cm}^{-2}}^{-2}$ & $0.8 \% \pm 0.2 \%$ & $77 \% \pm 2 \%$ & $88 \% \pm 1 \%$ \\
\hline
\end{tabular}

Table I. Photocytotoxicity of control and treated cells at $7.3 \times 10^{-7} \mathrm{M}$ of $\mathrm{mTHPC}$ (free and loaded)

Then the encapsulation of mTHPC in PLGA NPs did not seem to affect the PDT effect, even exhibiting better efficiency, while enabling to protect the cell of the natural toxicity of free mTHPC. This behaviour is similar to other results dealing with Foscan ${ }^{\circledR}$ encapsulation in solid lipid NPs ${ }^{6}$. Different irradiations were tested and it was concluded that irradiation can cause oxidation of lipids which are known to cause toxic reactions. Another study showed a 
significant improvement of the phototoxic reaction of a porphyrin after its encapsulation into biodegradable NPs ${ }^{39}$. These PLGA-NPs showed a high photocytotoxicity, leading to $85 \%$ of cellular death compared to $15 \%$ for the free porphyrin for a concentration of $3 \mu \mathrm{g} \cdot \mathrm{mL}^{-1}$ and an irradiation of $6 \mathrm{~J} . \mathrm{cm}^{-2}$.

Different parameters affect the therapeutic effect and different phenomena can occur depending of the type of NPs. The cellular uptake of mTHPC and its localisation can play an important role, that can be different before and after the encapsulation ${ }^{1,40,41}$. Moreover, the generation of reactive oxygen species can also be modified and influences the PDT effect ${ }^{40,42}$. The matrix nature is important because it can react with light too and can explain the better efficiency after PS encapsulation. In our case and compared to other results on PLGA NPs, it seems that the PLGA matrix is quite interesting as it improves the PDT efficiency while having perfect characteristics for injection (biocompatibility, biodegradation and controlled drug release).

As the aim of this work was not to find the best PDT conditions but to show the interest of our encapsulation strategy, it is clear that the results could be optimized either by increasing the mTHPC concentration within the NPs (while remaining in the non-toxic window for free mTHPC) or by playing with the irradiation conditions. Indeed, regarding the irradiation conditions, even if higher doses are currently used in clinical treatment ${ }^{43}$, current studies focused on the decrease of this fluence rate $e^{6,44}$. Using lower doses could avoid a cell death by necrosis, which is the case for higher irradiation doses. Indeed, the apoptosis mechanism is preferable to the cell necrosis as it does not imply the liberation of the cell content within the medium (which could contaminate the healthy cells and lead to their death) ${ }^{45,46}$. As the apoptosis is a longer process, it is then better to examine the cells a long time after irradiation. The annexin $\mathrm{V}$ test was then performed 40 hours after irradiation. Regarding the irradiation

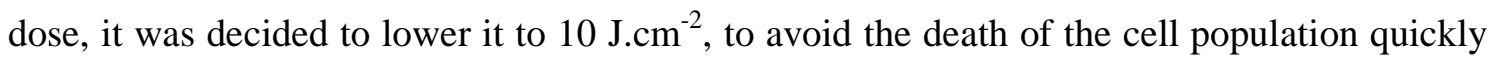




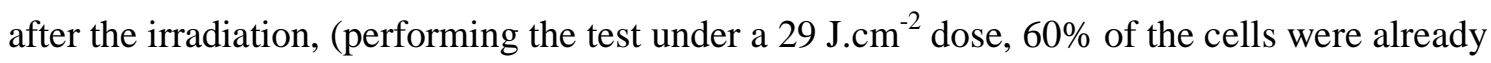
dead after $30 \mathrm{~min})$.

To investigate the biological aspect and the cell death mechanisms at lower irradiation doses, Annexin V tests were performed for the cells treated with free mTHPC and the loaded NPs (Fig. 7). Annexin V experiments enable to determine the mechanism of cell death by counting the percentage of cells in apoptosis. Contrary to the Trypan blue test performed in the first part of the study, the Annexin V test enables to distinguish the cells dead by necrosis or by apoptosis (this latter being the preferred mechanism for efficient PDT effect ${ }^{47-49}$ ) after irradiation, thanks to the detection of specific markers. One of them consists to localize phosphatidylserine normally contained in the internal face of membrane cell. Indeed, Annexin $\mathrm{V}$, which exhibits a high affinity for phosphatidylserines, can bind them only if they are located on the external surface of the cell membrane, which is the case if they are translocated to the outer surface of the cell membrane by externalization, during the early steps of the apoptosis process. . Regarding Annexin V and dead cell assay used in our experiments, a dead cell marker 7-Amino actinomycin D (7-AAD) was also used as an indicator of cell membrane structura since cells with damaged plasma membranes or with impaired/no cell metabolism are unable to prevent the dye from entering the cell. Once inside the cell, the dye binds to intracellular DNA, producing highly fluorescent adducts which identify the cells as "nonviable" or dead. In this case, necrosis mechanism is involved and phosphatidylserines will not be labelled by Annexin V staining anymore Four profiles can occur during analysis: for nonapoptotic cells, Annexin V is negative (-) and 7-AAD is negative (-); for early apoptotic cells, Annexin $\mathrm{V}$ is positive (+) and 7-AAD negative (-); for late step apoptotic and dead cells, Annexin $\mathrm{V}$ is positive (+) and 7-AAD positive (+); and for mostly nuclear debris, Annexin V is negative (-) and 7-AAD positive (+). After irradiation at $10 \mathrm{~J} . \mathrm{cm}^{-2}$ and 40 hours after the irradiation, as seen in Fig. 5A, the Annexin V tests exhibited an average death by apoptosis of 
$7 \pm 3 \%$ for the control cells treated with unloaded PLGA NPs, $75 \pm 5 \%$ for the cells treated with free mTHPC and of $89 \pm 4 \%$ for the cells treated with the mTHPC loaded NPs which confirmed the potentiality of the developed NPs for PDT treatments at low irradiation doses. Fig. 5B-D represent the typical AnnexinV apoptosis profile for the different conditions. In the literature, the death mechanism seems to depend on the PS concentration and the irradiation dose $\mathrm{e}^{44,50-53}$. In the case of mTHPC, both mechanisms have been shown to lead to the cellular death but with a better apoptosis rate compared to other $\mathrm{PS}^{54-56}$. In our case, using nanoparticles loaded with mTHPC with the proper irradiation dose and PS concentration enables to favor the death by apoptosis which is interesting for further clinical applications. 

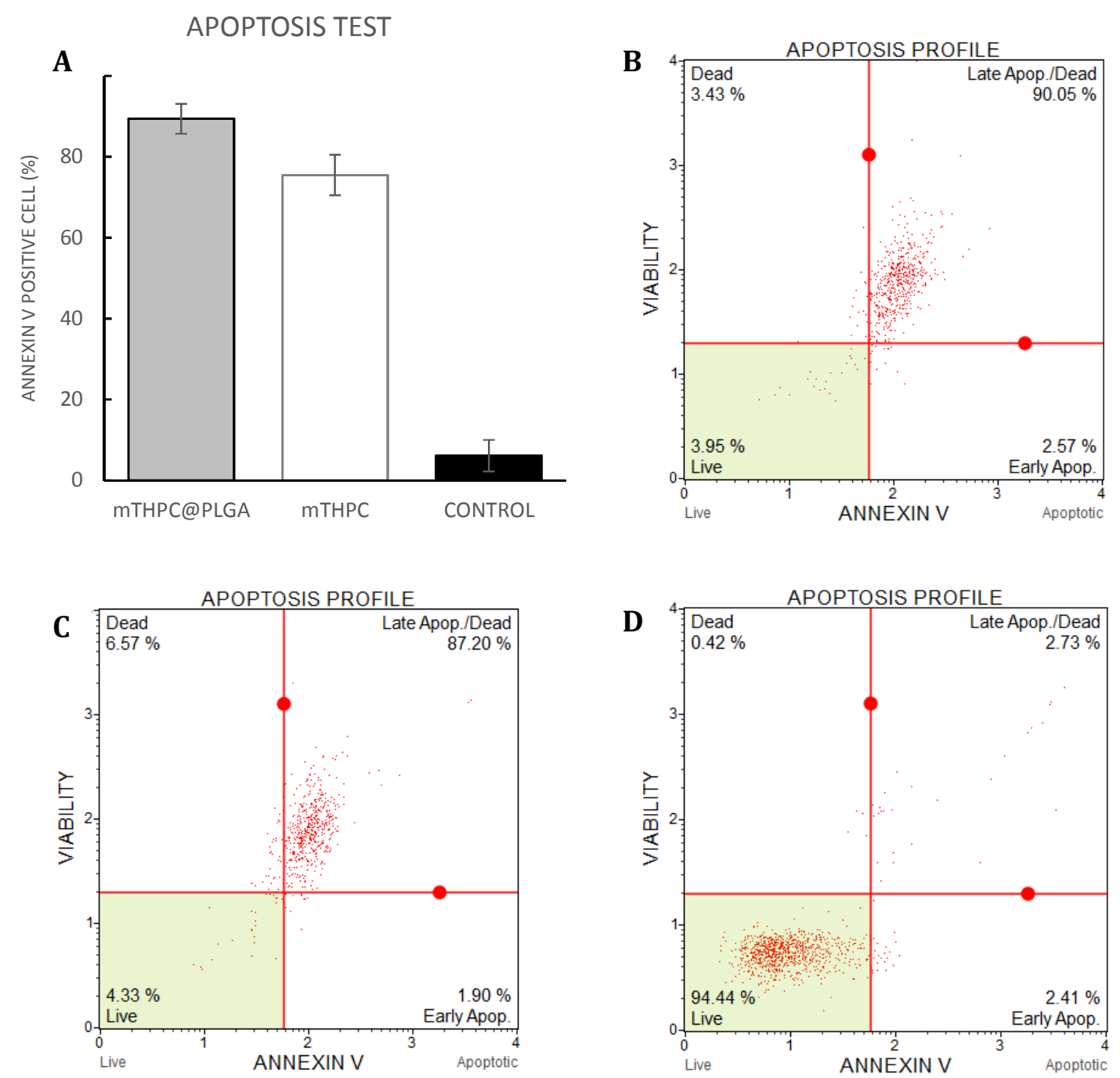

Fig 5: Results of Annexin V test for control and treated cells at $7.310^{-7} \mathrm{M}$ of $\mathrm{mTHPC}$ (free and loaded) (A). Average rates of apoptosis in mTHPC $\subset$ PLGA NPs compared to free $M T H P C$ and unloaded NP. Typical Annexin V Apoptosis profile for cells treated (B) with mTHPC loaded PLGA $N P s,(\boldsymbol{C})$ with free $m T H P C$ and $(D)$ unloaded PLGA NPs.

\section{Conclusion}

This study reported the encapsulation of a hydrophobic photosensitizer, the mTHPC, in

PLGA NPs. The main objective of this work was to obtain effective PS loaded biocompatible NPs for PDT applications. The physico-chemical characterizations show an efficient 
encapsulation of the mTHPC in the spherical PLGA NPs with proper sizes around $120 \mathrm{~nm}$ and adapted zeta-potential (around $-35 \mathrm{mV}$ ) for further injection. After a quick but limited release of the mTHPC

within the first 24 hours, the loaded NPs remain stable up to 5 days. Cytotoxicity experiments performed on C6 glioma cells show that contrary to free mTHPC, the loaded NPs remain nontoxic for concentration up to $10^{-5} \mathrm{M}$. Then the NPs loaded with a mTHPC concentration of $7.3 \times 10^{-7} \mathrm{M}$ to avoid a possible toxic effect after release were characterized from a PDT

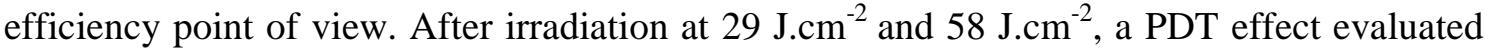
on C6 glioma cells is observed by optical and fluorescence experiments both for free mTHPC and mTHPC loaded NPs, with efficiency superior for the loaded NPs, leading to a cell death rate of $90 \%$ directly after irradiation. At lower irradiation dose $\left(10 \mathrm{~J} . \mathrm{cm}^{-2}\right)$ and by looking at the cells 40 hours after the irradiation, Annexin V tests show that for the used PS concentration, the cellular death occurred mainly by apoptosis for mTHPC incorporated within PLGA NPs. Then, mTHPC-loaded NPs could be envisaged as promising carriers for PDT treatments with improved characteristics compared to free mTHPC. Such system could avoid the pain occurring during the injection of mTHPC because of the use of ethanol while protecting the patient from the natural toxicity of mTHPC. As these NPs showed a lower cytotoxicity than the free PS, it allows to use higher concentration of PS if needed. 


\section{ACKNOWLEDGEMENTS}

G. Boeuf-Muraille and G. Rigaux thank the Region Champagne-Ardenne for their doctoral fellowship. Authors thank the Region Champagne-Ardenne and the EU-program FEDER for their financial support (Project C@Nano, NanoMat' and PICT platforms). The authors are very grateful to Biolitec Research $\mathrm{GmbH}$ for providing Foscan ${ }^{\circledR}$ used in this study. 


\section{REFERENCES}

1. Dougherty T.J., Gomer C.J., Henderson B.W., Jori G., Kessel D., Korbelik M., Moan J., Peng Q., Photodynamic therapy. J. Natl. Cancer Inst. 90, 889-905 (1998).

2. Macdonald I.J., Dougherty T.J., Basic principles of photodynamic therapy. J. Porphyr. Phthalocyanines 5, 105-129 (2001).

3. Bechet D., Couleaud P., Frochot C., Viriot M.-L., Guillemin F., Barberi-Heyob M., Nanoparticles as vehicles for delivery of photodynamic therapy agents. Trends Biotechnol. 26, 612-621 (2008).

4. Mitra S., Foster T.H., Photophysical parameters, photosensitizer retention and tissue optical properties completely account for the higher photodynamic efficacy of mesotetrahydroxyphenyl-chlorin vs photofrin, Photochem. Photobiol. 81, 849-859 (2005).

5. Triesscheijn M., Ruevekamp M., Out R., Van Berkel T.J., Schellens J., Baas P., Stewart F., The pharmacokinetic behavior of the photosensitizer meso-tetra-hydroxyphenylchlorin in mice and men, Cancer Chemother. Pharmacol. 60, 113-122 (2007).

6. Navarro F.P., Creusat G., Frochot C., Moussaron A., Verhille M., Vanderesse R., Thomann J.-S., Boisseau P., Texier I., Couffin A.-C., Barberi-Heyob M., Preparation and characterization of mTHPC-loaded solid lipid nanoparticles for photodynamic therapy. $J$. Photochem. Photobiol. B 130, 161-169 (2014).

7. Jain R. A., The manufacturing techniques of various drug loaded biodegradable poly(lactide-co-glycolide) (PLGA) devices. Biomaterials 21, 2475-904 (2000).

8. Brigger I., Dubernet C., Couvreur P., Nanoparticles in Cancer Therapy and Diagnosis. Adv. Drug Deliver. Rev. 54, 631-651 (2002).

9. Bose S., Bogner R.H., Solventless, Pharmaceutical Coating Processes: A Review. Pharm. Dev. Technol. 12, 115-131 (2007) 
10. Danhier F., Ansorena E., Silva J.M., Coco R., Le Breton A., Préat V., PLGA-based nanoparticles: An overview of biomedical applications. J Control Release 161, 505-522 (2012).

11. Maeda H., Tumor-Selective Delivery of Macromolecular Drugs via the EPR Effect: Background and Future Prospects. Bioconjug. Chem. 21, 797-802 (2010).

12. Nakamura Y., Mochida A., Choyke P.L., Kobayashi H., Nanodrug delivery: is the enhanced permeability and retention effect sufficient for curing cancer?, Bioconj. Chem. 27, 2225-2238 (2016)

13. Bœuf G., Roullin V.G., Moreau J., Van Gulick L., Zambrano Pineda N., Terryn C., Ploton D., Andry M.-C., Chuburu F., Dukic S., Molinari M., Lemercier G., Encapsulated ruthenium(II) complexes in biocompatible poly(D,L-lactide-co-glycolide) nanoparticles for application in photodynamic therapy. ChemPlusChem 79, 171-180 (2014).

14. Atif M., Fluorescence photobleaching dynamics of meso tetra hydroxy phenyl chlorin (mTHPC). Laser Phys. Lett. 9, 387-393 (2012).

15. Fessi H., Puisieux F., Devissaguet J. P., Ammoury N., Benita S., Nanocapsule formation by interfacial polymer deposition following solvent displacement. Int. J. Pharm. 55, R1R4 (1989).

16. Mosmann T., Rapid colorimetric assay for cellular growth and survival: application to proliferation and cytotoxicity assays. J. Immunol. Methods 65, 55-63 (1983).

17. Allison R.R., Sibata,C.H., Oncologic photodynamic therapy photosensitizers: A clinical review. Photodiagnosis Photodyn. Ther. 7, 61-75 (2010).

18. Rousset N., Kerninon E., Eléouet S., Le Néel T., Auget J.-L., Vonarx V., Carré J., Lajat Y., Patrice T., Use of alkaline Comet assay to assess DNA repair afterTHPC-PDT. $J$. Photochem. Photobiol. B 56, 118-131 (2000). 
19. Callewaert M., Dukic S., Van Gulick L., Vittier M., Gafa V., Andry M.-C., Molinari M., Roullin V.G., Etoposide encapsulation in surface-modified poly(lactide-co-glycolide) nanoparticles strongly enhances glioma antitumor efficiency. J. Biomed. Mater. Res. A 101A, 1319-1327 (2013).

20. Mora-Huertas C.E., Fessi H., Elaissari A., Polymer-based nanocapsules for drug delivery. Int. J. Pharm. 385, 113-142 (2010).

21. Courant T., Roullin V.G., Cadiou C., Delavoie F., Molinari M., Andry M.-C., Gafa V., Chuburu F., Nanotechnol. 21, 165101-165108 (2010).

22. Oyarzun-Ampuero F.A., Brea J., Loza M.I., Torres D., Alonso M.J., Int. J. Pharm. 381, $122-129$ (2009).

23. Sah H., Thoma L.A., Desu H.R., Sah E., Wood G.C., Int. J. Nanomedicine 8, 747-765 (2013).

24. Li M., Panagi Z., Avgoustakis K., Reineke J., Int. J. Nanomedicine 7, 1345-1356 (2012).

25. Löw K., Knobloch T., Wagner S., Wiehe A., Engel A., Langer K., von Briesen H., Comparison of intracellular accumulation and cytotoxicity of free $m$ THPC and $m$ THPCloaded PLGA nanoparticles in human colon carcinoma cells. Nanotechnology 22, 245102 (2011).

26. Hofman J.-W., Carstens M.G., van Zeeland F., Helwig C., Flesch F.M., Hennink W.E., van Nostrum C.F., Photocytotoxicity of mTHPC (Temoporfin) Loaded Polymeric Micelles Mediated by Lipase Catalyzed Degradation. Pharm. Res. 25, 2065-2073 (2008).

27. Rojnik M., Kocbek P., Moret F., Compagnin C., Celotti L., Bovis M.J., Woodhams J.H., MacRobert A.J., Scheglmann D., Helfrich W., Verkaik M.J., Papini E., Reddi E., Kos J., In vitro and in vivo characterization of temoporfin-loaded PEGylated PLGA nanoparticles for use in photodynamic therapy. Nanomed. 7, 663-677 (2012). 
28. Panyam J., Labhasetwar V., Biodegradable nanoparticles for drug and gene delivery to cells and tissue. Adv. Drug Deliv. Rev. 55, 329-347 (2003).

29. Kiesslich, T., Berlanda, J., Plaetzer, K., Krammer, B., Berr, F., Comparative characterization of the efficiency and cellular pharmacokinetics of Foscan- and Foslipbased photodynamic treatment in human biliary tract cancer cell lines. Photochem. Photobiol. Sci. 6, 619-627 (2007).

30. Kessel D., Sykes E., Transport, localization, and phototoxicity of m-THPC. in Proc. SPIE 3592, 37-42 (1999).

31. Melnikova V.O., Bezdetnaya L.N., Bour C., Festor E., Gramain M.-P., Merlin J.-L., Potapenko A.Y., Guillemin F., Subcellular localization of meta-tetra (hydroxyphenyl) chlorin in human tumor cells subjected to photodynamic treatment. J. Photochem. Photobiol. B 49, 96-103 (1999).

32. Leung W.N., Sun X., Mak N.K., Yow C.M.N., Photodynamic Effects of mTHPC on Human Colon Adenocarcinoma Cells: Photocytotoxicity, Subcellular Localization and Apoptosis. Photochem. Photobiol. 75, 406-411 (2002).

33. Teiten M.-H., Bezdetnaya L., Morlière P., Santus R., Guillemin F., Endoplasmic reticulum and Golgi apparatus are the preferential sites of Foscan ${ }^{\circledR}$ localisation in cultured tumour cells. Br. J. Cancer 88, 146-152 (2003).

34. Teiten M.-H., Marchal S., D’Hallewin M.A., Guillemin F., Bezdetnaya L., Primary Photodamage Sites and Mitochondrial Events after Foscan ${ }^{\circledR}$ Photosensitization of MCF-7 Human Breast Cancer Cells. Photochem. Photobiol. 78, 9-14 (2003).

35. Arndt-Jovin D.J., Jovin T.M., Fluorescence labeling and microscopy of DNA. Methods Cell Biol 30, 417-448 (1989). 
36. Panyam J., Labhasetwar V., Dynamics of Endocytosis and Exocytosis of Poly(D,LLactide-co-Glycolide) Nanoparticles in Vascular Smooth Muscle Cells. Pharm. Res. 20, $212-220(2003)$.

37. Panyam J., Zhou W.-Z., Prabha S., Sahoo, S.K, Labhasetwar V., Rapid endo-lysosomal escape of poly(dl-lactide-co-glycolide) nanoparticles: implications for drug and gene delivery. FASEB J. 16, 1217-1226 (2002).

38. Boyse E.A., Old L.J., Chouroulinkov I., Cytotoxic test for demonstration of mouse antibody. Methods Med Res 10, 39-47 (1964).

39. Konan Y.N., Berton M., Gurny R., Allémann E., Enhanced photodynamic activity of meso-tetra (4-hydroxyphenyl) porphyrin by incorporation into sub-200 nm nanoparticles. Eur. J. Pharm. Sci. 18, 241-249 (2003).

40. Bachor R., Shea C., Belmonte S., Hasan T., Free and conjugated chlorin e6 in the photodynamic therapy of human bladder carcinoma cells. J. Urol. 146, 1654-1658 (1991).

41. Peng Q., Moan J., Ma L.-W., Nesland J. M., Uptake, localization and photodynamic effect of meso-tetra(hydroxyphenyl)porphine and its corresponding chlorin in normal and tumor tissues of mice bearing mammary carcinoma. Cancer Res. 55, 2620-2626 (1995).

42. Bachor R., Shea C., Gillies R., Hasan T., Photosensitized destruction of human bladder carcinoma cells treated with chlorin e6-conjugated microspheres. Proc. Natl. Acad. Sci. 88, 1580-1584 (1991).

43. Moseley H., Light distribution and calibration of commercial PDT LED arrays. Photochem. Photobiol. Sci. 4, 911-914 (2005).

44. Pramual S., Lirdprapamongkol K., Svasti J., Bergkvist M., Jouan-Hureaux V., Arnoux P., Frochot C., Barberi-Heyob M., Niamsiri N., Polymer-lipid-PEG hybrid nanoparticles as photosensitizer carrier for photodynamic therapy. J. Photochem. Photobiol. B 173, 12-22 (2017). 
45. Luo Y., Kessel D., Initiation of apoptosis versus necrosis by photodynamic therapy with chloroaluminum phthalocyanine. Photochem. Photobiol. 66, 479-483 (1997).

46. Dellinger M., Apoptosis or necrosis following photofrin ${ }^{\circledR}$ photosensitization: influence of the incubation protocol. Photochem. Photobiol. 64, 182-187 (1996).

47. Kerr J. F.R., Wyllie A. H., Currie A. R., Apoptosis: a basic biological phenomenon with wide-ranging implications in tissue kinetics. Br. J. Cancer 26, 239-257 (1972).

48. Bourre L., Rousset N., Thibaut S., Eléouet S., Lajat Y., Patrice T., PDT effects of mTHPC and ALA, phototoxicity and apoptosis. Apoptosis 7, 221-230 (2002).

49. Lennon S.V., Martin S.J., Cotter T.G., Dose-dependent induction of apoptosis in human tumour cell lines by widely diverging stimuli. Cell Prolif. 24, 203-214 (1991).

50. Bacellar I., Tsubone T., Pavani C., Baptista M., Photodynamic Efficiency: From Molecular Photochemistry to Cell Death. Int. J. Mol. Sci. 16, 20523-20559 (2015).

51. Yoon J.-H., Yoon H.-E., Kim O., Kim S.K., Ahn S.-G., Kang K.W., The enhanced anticancer effect of hexenyl ester of 5-aminolaevulinic acid photodynamic therapy in adriamycin-resistant compared to non-resistant breast cancer cells. Lasers Surg. Med. 44, 76-86 (2012).

52. Soriano J., Mora-Espí I., Alea-Reyes M.E., Pérez-García L., Barrios L., Ibáñez E., Nogués C., Cell Death Mechanisms in Tumoral and Non-Tumoral Human Cell Lines Triggered by Photodynamic Treatments: Apoptosis, Necrosis and Parthanatos. Sci. Rep. 7, 41340 (2017).

53. Soriano J., García-Díaz M., Mora M., Sagristá M.L., Nonell S., Villanueva A., Stockert J.C., Cañete M., Liposomal temocene (m-THPPo) photodynamic treatment induces cell death by mitochondria-independent apoptosis. Biochim. Biophys. Acta BBA - Gen. Subj. 1830, 4611-4620 (2013). 
54. Chen, J. Y., Mak N.K., Wen J.M., Leung W.N., Chen S.C., Fung M.C., Cheung N.H, A comparison of the photodynamic effects of temoporfin (mTHPC) and MC540 on leukemia cells: efficacy and apoptosis. Photochem. Photobiol. 68, 545-554 (1998).

55. Kirveliene V., Sadauskaite A., Kadziauskas J., Sasnauskiene S., Juodka, B., Correlation of death modes of photosensitized cells with intracellular ATP concentration. FEBS Lett. 553, 167-172 (2003).

56. Kirveliene V., Prasmickaite L., Kadziauskas J., Bonnett R., Djelal B.D., Juodk B., Postexposure processes in Temoporfin-photosensitized cells in vitro: reliance on energy metabolism. J. Photochem. Photobiol. B 41, 173-180 (1997). 